\title{
Impact of the Mining Activity on the Water Quality in Peru Applying the Fuzzy Logic with the Grey Clustering Method
}

\author{
Alexi Delgado ${ }^{1}$, Anabel Fernandez ${ }^{2}$, Brigitte Chirinos ${ }^{3}$, Gabriel Barboza ${ }^{4}$, Enrique Lee Huamaní ${ }^{5}$ \\ Mining Engineering Section, Pontificia Universidad Católica del Perú, Lima-Perú ${ }^{1}$ \\ Facultad de Ingeniería Ambiental, Universidad Nacional de Ingeniería, Lima, Perú 23,4 \\ Image Processing Research Laboratory, Universidad de Ciencias y Humanidades, Lima-Perú ${ }^{5}$
}

\begin{abstract}
Mining activity in the department of Junín, Peru, is intense, due to the great existing mining-metallic potential that exists in the place, the Yauli and Andaychagua rivers, located in the Yauli Province, belonging to Junín, receive a large volume of discharges causing deterioration in the quality of the water of these rivers. To evaluate this quality in an integral way, fuzzy logic will be applied with the Grey Clustering methodology, defining the central point triangular whitening weight functions (CTWF), having as grey classes the Environmental Quality Standards for water (ECA-Water), Category 3, which were modified for research purposes. Four monitoring points were evaluated, both upstream (point PY-01) and downstream (PY-02) of the Yauli River; as upstream (PA-01) and downstream (PA02) of the Andaychagua river. From the analysis it was determined that the water quality in PY-01 is $0.7302,0.8795$ in the dry season and 0.5980 in the wet season; in PY-02, 0.5448, 0.6448 in dry season and 0.5628 in wet season were obtained. At point PA-01 it is $0.8213,0.8691$ in dry season and 0.7902 in wet season; In PA-02, $0.8385,0.8827$ in the dry season and 0.8118 in the wet season were obtained, concluding that there is good water quality, decreasing in wet seasons, this due to the influence of the rains in the contact waters. The research provides an integration of the parameters that are considered in the ECA-Water with other international standards allowing to determine a more precise evaluation of the quality status of the Yauli and Andaychagua rivers after receiving the effluents generated by the mining activity, benefiting the relevant authorities for decision making and providing a methodology that improves the analysis of the results obtained by the specific parameters that are evaluated in the environmental monitoring.
\end{abstract}

\section{Keywords-Mining activity; water quality; grey clustering}

\section{INTRODUCTION}

The department of Junín, in Peru, is divided into 07 metallogenic strips. These strips represent periods of mineralization that extend along regional fault systems and the lithologies that have favored the mineralization of polymetallic mineral deposits of economic interest [1]. This is why it is an ideal place for the exploitation of minerals, a situation that has led many mining companies to grant concessions to a large percentage of this department to carry out the extraction of minerals. In other words, it is an area with great polymetallic mining activity but also with an excessive discharge of acidic waters that contaminate the environment [2].
Based on the above, a particular case will be evaluated regarding the activity of two mining units in the province of Yauli, belonging to the department of Junín, due to the discharge of its effluents affecting, mainly, the rivers that serve as receiving bodies for such effluents, the Yauli and Andaychagua rivers. The Yauli and Andaychagua Rivers are the first to receive the greatest concentration and influence of mining activities in the Junín Region [3], since mining activity is intense, so a large volume of discharges must be evacuated, some of them directly and others in the tailings ponds [4].

The grey system theory is a useful methodology for systems with incomplete information. Grey relational analysis can be used to analyze relationships between one of the main ones, as a reference, and the others to establish a certain comparison [5].

Grey Clustering is a method that can be applied by incidence of grey matrices or grey bleaching weight functions. In this work, we use triangular center-point whitening weight functions (CTWF), since CTWF are applied mainly to test if the observation objects belong to predetermined classes, called grey classes [6], as shown by the decision making studies [7], to determine key indicators [8], for the evaluation of safety management [9], project location selection [10], air quality assessment [11], water resources management. The CTWF could be applied to classify monitoring points in water quality assessment; therefore, in this study 4 monitoring points will be identified, both upstream, and downstream of the Yauli and Andaychagua rivers, taking as standard values the environmental water quality standards, category 3, using the CTWF method.

Based on the information presented, the specific objective is to analyze the impact caused by two mining units when they discharge their effluents into the Yauli and Andaychagua rivers by applying the Grey Clustering methodology, to subsequently compare the water quality of both rivers and determine where the greatest impact is required on the treatment of these effluents, prior to discharge.

In the present work, Section II briefly summarizes the main background taken as reference for the research; Section III shows details about the CTWF method; Section IV describes the case study, followed by the results and 
discussion of them in Section V. Finally, the conclusions are presented in Section IV.

\section{LITERATURE REVIEW}

An investigation on an artificial intelligence model based on grey systems to evaluate the water quality of the Santa River basin is presented [12], in which with the grey grouping method the water quality was evaluated using the artificial intelligence criteria together with the data from twenty-one monitoring points of the Santa River of the National Water Authority of Peru (ANA) in comparison with parameters established by MINAM-Peru (DS No 015-2015). The results showed that $47.6 \%$ of the monitoring points had good water quality for the population's consumption, $33.3 \%$ of the points had moderate water quality and $19.1 \%$ had low water quality for the population's consumption.

The investigation to determine the water quality of five water bodies in the Rimac River Basin [13] which belong to Category 1 A2: "Population and Recreation" with the application of the Grey Clustering analysis methodology and the Prati water quality index. The five bodies of water under study were determined to be uncontaminated, which gives them the characteristics of belonging to Category $1 \mathrm{~A} 2$, since they do not represent a risk to human health and can be made drinkable through conventional treatment.

The case of the evaluation of drinking water consumption in the city of Lima is presented using the Grey Clustering method [14]. The evaluation was carried out in 32 districts of Lima, Peru, and resulted in a map of the drinking water consumption situation. These results revealed that the districts that consume the most water are San Isidro, Miraflores, La Molina, San Borja and Lince; and those that consume the least were Ancón, Puente Piedra, Villa el Salvador and Independencia.

On the other hand, an application was made in the integral evaluation of the water environment quality of Zhalong wetland based on the grey grouping method [15], for which the criteria of the water quality classification standard GB 3838-2002 were used, where the degree of contamination is divided into 5 levels. As a result, water pollution was very severe in the area studied, which is caused by the mutual interaction of water scarcity, contaminants above the test standard, and internal pollution, while water scarcity is the main factor of pollution.

There is also an application of the Grey Clustering method for the evaluation of surface water quality [16] and the analysis of results showed that the water quality of Shuangliao was of first degree and slightly contaminated, the water quality of Lanhezha, Liaoyuan, second and fourth degree, while for the water of Erlongshan reservoir, Siping and Yitong were in fifth degree seriously contaminated.

\section{MethodOLOGY}

For the grey grouping method, $\mathrm{m}$ monitoring points and a set of $\mathrm{n}$ water quality parameters are taken, being these $\mathrm{x}_{-} \mathrm{ij}$ $(\mathrm{i}=1,2, \ldots, \mathrm{m} ; \mathrm{j}=1,2, \ldots, \mathrm{n})[6]$.

The next steps of the method are as follows:
Step 1: First the standard values for each water quality parameter (j) are sized according to Peruvian and foreign regulations for water quality for irrigation of vegetables and drinking of animals

Step 2: The classes of flock on the water parameters taken are plotted as shown in Fig. 1.

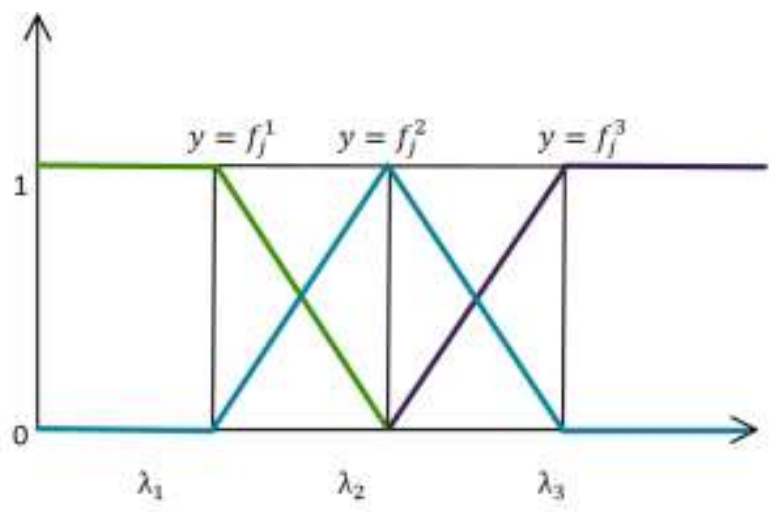

Fig. 1. Clustering Function Chart.

Where:

$y=f_{j}^{1}=A 1=$ Good quality water for watering

$y=f_{j}^{2}=A 2=$ Moderate water quality for watering

$y=f_{j}^{3}=A 3=$ SPoor quality water for watering

Now we present the triangular center-point whitening weight (CTWF) functions for each of the established parameters, for the $\mathrm{k}$-th class grey, $\mathrm{k}=1,2,3$, of the $\mathrm{j}$-th parameter, $\mathrm{j}=1,2, \ldots, \mathrm{n}$, for a monitoring value xij by Eq. 1-3.

$f_{1}^{1}\left(x_{i j}\right)=\left\{\begin{array}{c}1, \quad x \in\left[0, \lambda_{j}^{1}\right] \\ \frac{\lambda_{j}^{2}-x}{\lambda_{j}^{2}-\lambda_{j}^{1}}, \quad x \in\left[\lambda_{j}^{1}, \lambda_{j}^{2}\right] \\ 0, x \in\left[\lambda_{j}^{2},+\propto\right]\end{array}\right.$

$f_{1}^{2}\left(x_{i j}\right)=\left\{\begin{array}{c}\frac{x-\lambda_{j}^{1}}{\lambda_{j}^{2}-\lambda_{j}^{1}}, \quad x \in\left[\lambda_{j}^{1}, \lambda_{j}^{2}\right] \\ \frac{\lambda_{j}^{3}-x}{\lambda_{j}^{3}-\lambda_{j}^{2}}, \quad x \in\left[\lambda_{j}^{2}, \lambda_{j}^{3}\right] \\ 0, x \notin\left[\lambda_{j}^{1}, \lambda_{j}^{3}\right]\end{array}\right.$

$f_{1}^{3}\left(x_{i j}\right)=\left\{\begin{array}{c}\frac{x-\lambda_{j}^{2}}{\lambda_{j}^{3}-\lambda_{j}^{2}}, \quad x \in\left[\lambda_{j}^{2}, \lambda_{j}^{3}\right] \\ 1, x \in\left[\lambda_{j}^{3},+\propto\right] \\ 0, x \in\left[0, \lambda_{j}^{2}\right]\end{array}\right.$

Step 3: To determine the weights of each established parameter $\left(n_{i j}\right)$, the statistical procedure of harmonic mean is established as follows. Eq. 4.

$n_{j}^{k}=\frac{\frac{1}{\lambda_{j}^{k}}}{\sum_{j=1}^{m} \frac{1}{\lambda_{j}^{k}}}$ 
Step 4: The integral grouping coefficient $\sigma \mathrm{i}^{\wedge} \mathrm{k}$ for each monitoring point $\mathrm{i}, \mathrm{i}=1,2, \ldots \mathrm{m}$, with respect to the grey classes $\mathrm{k}, \mathrm{k}=1,2,3$, is calculated with the following equation. Eq. 5:

$\sigma_{i}^{k}=\sum_{j=1}^{n} f_{j}^{k}(x i j) . n j$

Step 5: We determine the results using the Max clustering coefficient, as shown in Eq. 6, and decide that object i belongs to the $\mathrm{k}^{*}$ grey class. When there are several objects in the $\mathrm{k}^{*}$ grey class, these objects can be sorted according to the magnitudes of their full clustering coefficients.

$\max _{1 \leq k \leq S}\left\{\sigma_{i}^{k}\right\}=\sigma_{i}^{k^{*}}$

\section{CASE STUdY}

The Yauli and Andaychagua rivers are located in the province of Yauli, department of Junín, where mining activity is intense, so there is a large volume of discharges, some of them directly (mine water, domestic wastewater) and others in the tailing ponds [4].

\section{A. Definition of Objects of Study}

Four upstream and downstream monitoring points were analyzed for the Yauli River with respect to mining activity and for the Andaychagua River in the same manner. Upstream of the monitoring points for the Yauli river is the town center of Yauli and downstream is the Pomacocha lagoon. For the Andaychagua river the closest body of water is the Aguascocha lagoon, which is downstream.

Fig. 2 and Fig. 3 show the monitoring points for the Yauli and Andaychagua rivers, respectively.

Points PY-01 and PA-01 belong to the upstream stations of each river in the project and points PY-02 and PA-02 downstream, in addition to each monitoring point was evaluated for wet and dry season. As shown in Table I.

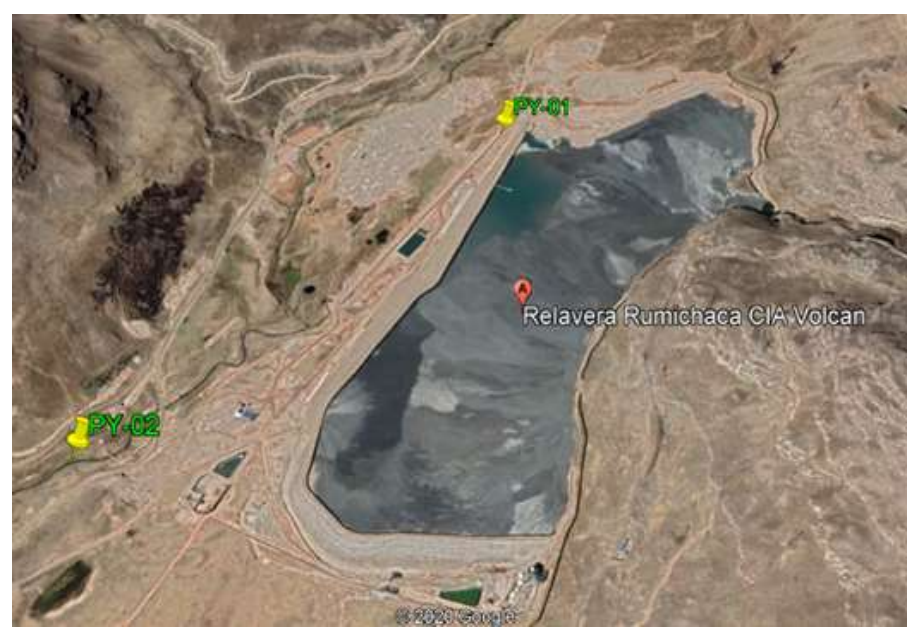

Fig. 2. Monitoring Points in the Upstream and Downstream Yauli River.

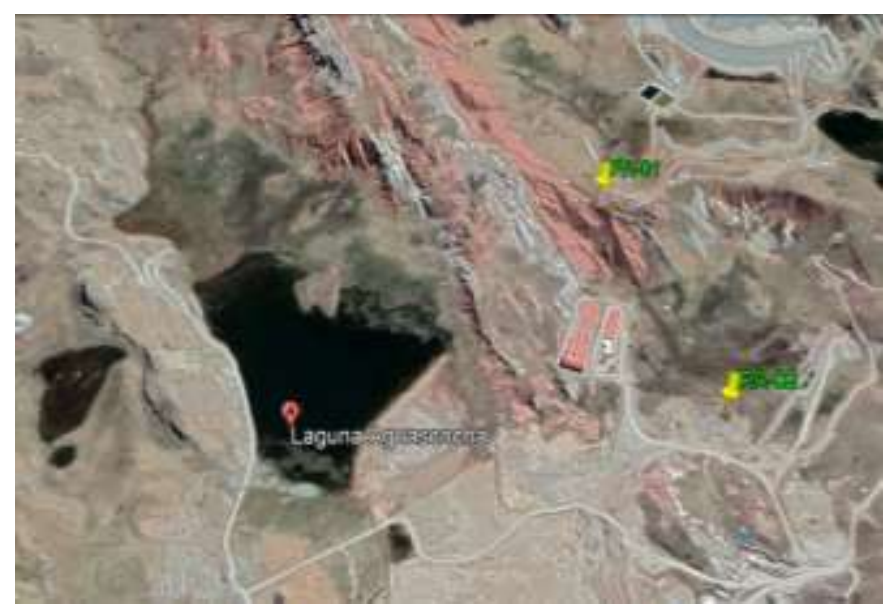

Fig. 3. Monitoring Points in the Andaychagua River, Upstream and Downstream.

TABLE I. LOCATION OF MONITORING POINTS

\begin{tabular}{|l|l|l|}
\hline Monitoring points & Location \\
\hline & Eastern Coordinated & North Coordinator \\
\hline PY-01 & $379109.00 \mathrm{~m} \mathrm{E}$ & $8706069.00 \mathrm{~m} \mathrm{~S}$ \\
\hline PY-02 & $380082.00 \mathrm{~m} \mathrm{E}$ & $8706894.00 \mathrm{~m} \mathrm{~S}$ \\
\hline PA-01 & $340218.00 \mathrm{~m} \mathrm{E}$ & $8759747.00 \mathrm{~m} \mathrm{~S}$ \\
\hline PA-02 & $340450.00 \mathrm{~m} \mathrm{E}$ & $8759243.00 \mathrm{~m} \mathrm{~S}$ \\
\hline
\end{tabular}

B. Definition of Evaluation Criteria

The evaluation criteria for the study were taken from Peruvian regulations and international standards to obtain a range of specificity regarding water quality, these are.

1) Dissolved oxygen: The RCT for water in the Peruvian regulations [17] establishes values $>5 \mathrm{mg} / \mathrm{L}$ and $4 \mathrm{mg} / \mathrm{L}$ for irrigation and animal drinking, a more restrictive value taken to consider water quality good was $>7.5 \mathrm{mg} / \mathrm{L}$ which belongs to the Chilean legislation [18] for water destined for unrestricted irrigation.

2) Hydrogen potential: The ECA for water of the Peruvian regulations [17] establishes values of 6.5-8-5 and 6.5-8.4 of $\mathrm{pH}$ for irrigation of vegetables and drink of animals. One value taken was from the Water Law [19] with a $\mathrm{pH}$ value of 5-9 units.

3) Arsenic: The RCT for water in the Peruvian regulations [17] establishes values of $0.1 \mathrm{mg} / \mathrm{L}$ and $0.2 \mathrm{mg} / \mathrm{L}$ for irrigation of vegetables and drinking water for animals. A more restrictive value was taken from the Regulations for the Control of Water Bodies in Venezuela [20], with a value of $0.05 \mathrm{mg} / \mathrm{L}$ of Arsenic for water intended for drinking water for livestock. 
4) Cadmium: The ECA for water of the Peruvian regulations [17] establishes values of $0.01 \mathrm{mg} / \mathrm{L}$ and $0.05 \mathrm{mg} / \mathrm{L}$ for irrigation of vegetables and animal beverages, a more restrictive value was $0.001 \mathrm{mg} / \mathrm{L}$ which belongs to the Draft Quality Standard for the Protection of Continental Surface Water in Chile [18], in waters destined to restrictive irrigation.

5) Coppe: The ECA for water of the Peruvian regulations [17] establishes values of $0.2 \mathrm{mg} / \mathrm{L}$ and $0.5 \mathrm{mg} / \mathrm{L}$ for irrigation of vegetables and animal beverages, a more restrictive value was $0.002 \mathrm{mg} / \mathrm{L}$, which belongs to the Draft Quality Standard for the Protection of Continental Surface Water in Chile [18], in waters destined to restrictive irrigation.

6) Cobalt: The RCT for water of the Peruvian regulations [17] establishes values of $0.05 \mathrm{mg} / \mathrm{L}$ and $1 \mathrm{mg} / \mathrm{L}$ for irrigation of vegetables and animal beverages, a value that was taken as an intermediate was $0.1 \mathrm{mg} / \mathrm{L}$ which was established in an investigation carried out by the FAO [21].

7) Iron: The ECA for water of the Peruvian regulations [17] establishes values of $5 \mathrm{mg} / \mathrm{L}$ for irrigation of vegetables and animal beverages. Two more restrictive values were chosen: $1 \mathrm{mg} / \mathrm{L}$, established in the General Water Law [19], and $0.3 \mathrm{mg} / \mathrm{L}$, which corresponds to the Draft Quality Standard for the Protection of Inland Surface Water in Chile, for water intended for restrictive irrigation.

8) Magnesium: The ECA for water in the Peruvian regulations [17] establishes values of $250 \mathrm{mg} / \mathrm{L}$ for irrigation of vegetables and animal beverages. Two more restrictive values were chosen, which were $150 \mathrm{mg} / \mathrm{L}$ established in the General Water Law [19] and 70mg/L established in the Standard for the Control of the Quality of Venezuelan Water Bodies [20], for water intended for the irrigation of vegetables, legumes consumed raw, cereals and tree crops.

9) Manganese: The ECA for water in the Peruvian regulations [17] establishes values of $0.2 \mathrm{mg} / \mathrm{L}$ for irrigation of vegetables and animal beverages. Two more restrictive values were chosen, which were $0.05 \mathrm{mg} / \mathrm{L}$ established in the Draft Quality Standard for the Protection of Inland Surface Water in Chile [18], in waters intended for restrictive irrigation and a value of $0.125 \mathrm{mg} / \mathrm{L}$ being a midpoint between the two extremes.

10)Mercury: The ECA for water in the Peruvian regulations [17] establishes values of $0.001 \mathrm{mg} / \mathrm{L}$ and $0.01 \mathrm{mg} / \mathrm{L}$ for irrigation of vegetables and animal beverages, a more restrictive value was $0.0002 \mathrm{mg} / \mathrm{L}$ in the Standard to Prevent Environmental Contamination in Paraguay [22], in water intended for irrigation of vegetables or fruit plants or crops intended for human consumption.
11)Nickel: The ECA for water in the Peruvian regulations [17] establishes values of $0.2 \mathrm{mg} / \mathrm{L}$ and $1 \mathrm{mg} / \mathrm{L}$ for irrigation of vegetables and animal beverages, a more restrictive value was $0.002 \mathrm{mg} / \mathrm{L}$ in the General Water Law [19], for irrigation water for raw vegetables and animal beverages.

12)Lead: The ECA for water in the Peruvian regulations [17] establishes values of $0.05 \mathrm{mg} / \mathrm{L}$ for irrigation of vegetables and animal beverages. Two more restrictive values were chosen, which were $0.001 \mathrm{mg} / \mathrm{L}$, belonging to the Draft Quality Standard for the Protection of Continental Surface Water in Chile [18], for water intended for restrictive irrigation, and $0.03 \mathrm{mg} / \mathrm{L}$ in the Standard to prevent environmental pollution in Paraguay [22], for water intended for irrigation of vegetables or fruit plants.

13)Selenium: The ECA for water in the Peruvian regulations [17] establishes values of $0.02 \mathrm{mg} / \mathrm{L}$ and $0.05 \mathrm{mg} / \mathrm{L}$ for irrigation of vegetables and animal beverages, a more restrictive value was $0.005 \mathrm{mg} / \mathrm{L}$ which corresponds to the Draft Quality Standard for the Protection of Inland Surface Water in Chile [18], in waters destined for restrictive irrigation.

14)Nickel: The ECA for water in the Peruvian regulations [17] establishes values of $0.2 \mathrm{mg} / \mathrm{L}$ and $1 \mathrm{mg} / \mathrm{L}$ for irrigation water for vegetable and animal beverages, a more restrictive value was $0.002 \mathrm{mg} / \mathrm{L}$ in the General Water Law [19], for irrigation water for raw vegetable and animal beverages.

\section{Definition of the Grey Classes}

The parameters chosen were based on the ECA category 3 of the Peruvian regulations together with international regulations in order to have a range of 3 types of water quality for the ECA, taking as a basis that the already established Peruvian regulations cannot be exceeded, presenting the final result below.

\section{Calculations with Grey Clustering}

The calculations in this case study are based on CTWF methods, which are presented as follows.

Step 1: First the parameters chosen for the case study were sized as detailed in Table III.

Points 1 to 6 are from the Yauli River, differentiated by time of year as shown in Table IV. Similarly, points 1 to 7 are from the Andaychagua River.

Then, the dimensioned monitoring data of all points to be studied is shown, Table V.

Points 1 to 6 are from the Yauli River, differentiated by time of year as shown in Table IV. Similarly, points 1 to 7 are from the Andaychagua River. 
TABLE II. VALUES TAKEN FOR THE CASE StUdy

\begin{tabular}{|l|l|l|l|l|}
\hline Parameters & Unit of measure & Good & Moderated & Bad \\
\hline $\mathrm{OD}$ & $\mathrm{mg} / \mathrm{L}$ & 7.5 & 5 & 4 \\
\hline $\mathrm{pH}$ & $\mathrm{pH}$ & 7 & 7.45 & 7.75 \\
\hline $\mathrm{As}$ & $\mathrm{mg} / \mathrm{L}$ & 0.05 & 0.1 & 0.2 \\
\hline $\mathrm{Cd}$ & $\mathrm{mg} / \mathrm{L}$ & 0.001 & 0.01 & 0.05 \\
\hline $\mathrm{Cu}$ & $\mathrm{mg} / \mathrm{L}$ & 0.002 & 0.2 & 0.5 \\
\hline $\mathrm{Co}$ & $\mathrm{mg} / \mathrm{L}$ & 0.05 & 0.1 & 1 \\
\hline $\mathrm{Fe}$ & $\mathrm{mg} / \mathrm{L}$ & 0.3 & 1 & 5 \\
\hline $\mathrm{Mg}$ & $\mathrm{mg} / \mathrm{L}$ & 70 & 151 & 0.125 \\
\hline $\mathrm{Mn}$ & $\mathrm{mg} / \mathrm{L}$ & 0.05 & 0.001 & 251 \\
\hline $\mathrm{Hg}$ & $\mathrm{mg} / \mathrm{L}$ & 0.0002 & & 0.2 \\
\hline $\mathrm{Ni}$ & $\mathrm{mg} / \mathrm{L}$ & 0.002 & 0.03 & 0.01 \\
\hline $\mathrm{Pb}$ & $\mathrm{mg} / \mathrm{L}$ & 0.001 & 0.02 & 0.1 \\
\hline $\mathrm{Se}$ & $\mathrm{mg} / \mathrm{L}$ & 0.005 & 2 & 0.05 \\
\hline $\mathrm{Zn}$ & $\mathrm{mg} / \mathrm{L}$ & 0.03 & \\
\hline
\end{tabular}

TABLE III. DIMENSIONED CRITERIA

\begin{tabular}{|l|l|l|l|l|}
\hline Parameters & Criteria & Good & Moderated & Bad \\
\hline $\mathrm{OD}$ & $\mathrm{C} 1$ & 1.3636 & 0.9091 & 0.7273 \\
\hline $\mathrm{pH}$ & $\mathrm{C} 2$ & 0.9459 & 1.0068 & 1.0473 \\
\hline $\mathrm{As}$ & $\mathrm{C} 3$ & 0.4286 & 0.8571 & 1.7143 \\
\hline $\mathrm{Cd}$ & $\mathrm{C} 4$ & 0.0492 & 0.4918 & 2.4590 \\
\hline $\mathrm{Cu}$ & $\mathrm{C} 5$ & 0.0085 & 0.8547 & 2.1368 \\
\hline $\mathrm{Co}$ & $\mathrm{C} 6$ & 0.1304 & 0.2609 & 2.6087 \\
\hline $\mathrm{Fe}$ & $\mathrm{C} 7$ & 0.1429 & 0.4762 & 2.3810 \\
\hline $\mathrm{Mg}$ & $\mathrm{C} 8$ & 0.4449 & 1.0000 & 1.5953 \\
\hline $\mathrm{Mn}$ & $\mathrm{C} 9$ & 0.4000 & 0.2679 & 1.6000 \\
\hline $\mathrm{Hg}$ & $\mathrm{C} 10$ & 0.0536 & 1.9868 & 2.6786 \\
\hline $\mathrm{Ni}$ & $\mathrm{C} 11$ & 0.0199 & 1.1111 & 0.9934 \\
\hline $\mathrm{Pb}$ & $\mathrm{C} 12$ & 0.0370 & 0.8000 & 1.8519 \\
\hline $\mathrm{Se}$ & $\mathrm{C} 13$ & 0.2000 & 0.2305 & 2.0000 \\
\hline $\mathrm{Zn}$ & $\mathrm{C} 14$ & 0.0035 & & 2.7660 \\
\hline
\end{tabular}

TABLE IV. DESCRIPTION OF POINTS

\begin{tabular}{|l|l|l|}
\hline Monitoring Points & Data & Description \\
\hline 1 & PY-01-H & Yauli River upstream, wet season \\
\hline 2 & PY-01-S & Yauli River upstream, dry season \\
\hline 3 & PY-02-H & Yauli River downstream, wet season \\
\hline 4 & PY-02-S & Yauli River downstream, dry season \\
\hline 5 & PY-01 & Yauli River upstream \\
\hline 6 & PY-02 & Yauli River downstream \\
\hline 7 & PA-01-H & Andaychagua River upstream, wet season \\
\hline 8 & PA-01-S & Andaychagua River upstream, dry season \\
\hline 9 & PA-02-H & Andaychagua River downstream, wet season \\
\hline 10 & PA-02-S & Andaychagua River downstream, dry season \\
\hline 11 & PA-01 & Andaychagua River upstream \\
\hline 12 & PA-02 & Andaychagua River downstream \\
\hline
\end{tabular}


TABLE V. REAL VALUES ARE DiMENSIONED

\begin{tabular}{|c|c|c|c|c|c|c|}
\hline Points Parameters & 1 & 2 & 3 & 4 & 5 & 6 \\
\hline $\mathrm{C} 1$ & 1.1197 & 1.2982 & 1.4709 & 4.4655 & 1.2090 & 2.9682 \\
\hline $\mathrm{C} 2$ & 1.0948 & 1.1003 & 0.0196 & 1.0865 & 1.0976 & 0.5530 \\
\hline $\mathrm{C} 3$ & 1.3527 & 0.3739 & 0.0171 & 0.5314 & 0.8633 & 0.2743 \\
\hline $\mathrm{C} 4$ & 0.0344 & 0.0123 & 3.7869 & 0.0984 & 0.0234 & 1.9426 \\
\hline $\mathrm{C} 5$ & 0.3393 & 0.1058 & 0.0128 & 0.1026 & 0.2225 & 0.0577 \\
\hline C6 & 0.0048 & 0.0030 & 9.9052 & 0.0052 & 0.0039 & 4.9552 \\
\hline $\mathrm{C} 7$ & 1.4577 & 0.2118 & 17.4552 & 0.4733 & 0.8347 & 8.9643 \\
\hline $\mathrm{C} 8$ & 0.1866 & 0.2238 & 0.0913 & 0.2987 & 0.2052 & 0.1950 \\
\hline $\mathrm{C} 9$ & 21.6917 & 6.2302 & 0.0000 & 145.696 & 13.9610 & 72.8480 \\
\hline $\mathrm{C} 10$ & 0.0268 & 0.0268 & 0.5357 & 0.0000 & 0.0268 & 0.2679 \\
\hline $\mathrm{C} 11$ & 0.0079 & 0.0055 & 1.0728 & 0.0099 & 0.0067 & 0.5414 \\
\hline $\mathrm{C} 12$ & 2.6500 & 1.0491 & 0.0370 & 1.7037 & 1.8495 & 0.8704 \\
\hline $\mathrm{C} 13$ & 0.0420 & 0.0200 & 43.3200 & 0.0400 & 0.0310 & 21.6800 \\
\hline $\mathrm{C} 14$ & 0.1096 & 0.0206 & 0.1244 & 0.1147 & 0.0651 & 0.1195 \\
\hline Points Parameters & 7 & 8 & 9 & 10 & 11 & 12 \\
\hline $\mathrm{C} 1$ & 1.1462 & 1.1467 & 1.1997 & 1.1582 & 1.1465 & 1.1790 \\
\hline $\mathrm{C} 2$ & 1.1003 & 1.0254 & 1.1191 & 1.0686 & 1.0629 & 1.0938 \\
\hline $\mathrm{C} 3$ & 0.9139 & 0.4665 & 1.4050 & 0.7886 & 0.6902 & 1.0968 \\
\hline $\mathrm{C} 4$ & 0.0190 & 0.0111 & 0.0492 & 0.0123 & 0.0150 & 0.0307 \\
\hline $\mathrm{C} 5$ & 0.3409 & 0.0746 & 0.1685 & 0.0760 & 0.2078 & 0.1222 \\
\hline C6 & 0.0013 & 0.0014 & 0.0107 & 15.6569 & 0.0014 & 7.8338 \\
\hline $\mathrm{C} 7$ & 0.7506 & 0.7964 & 0.8219 & 0.5008 & 0.7735 & 0.6613 \\
\hline $\mathrm{C} 8$ & 0.0696 & 0.1444 & 0.0985 & 0.1137 & 0.1070 & 0.1061 \\
\hline C9 & 4.4819 & 8.7354 & 4.4881 & 5.6736 & 6.6087 & 5.0809 \\
\hline $\mathrm{C} 10$ & 0.0268 & 0.0268 & 0.0268 & 0.0268 & 0.0268 & 0.0268 \\
\hline $\mathrm{C} 11$ & 0.0043 & 0.0045 & 0.0545 & 0.0263 & 0.0044 & 0.0404 \\
\hline $\mathrm{C} 12$ & 1.7737 & 0.7584 & 2.2440 & 1.0481 & 1.2660 & 1.6461 \\
\hline $\mathrm{C} 13$ & 0.0280 & 0.0230 & 0.0269 & 0.0240 & 0.0255 & 0.0254 \\
\hline C14 & 0.0263 & 0.0296 & 0.0349 & 0.0104 & 0.0279 & 0.0227 \\
\hline
\end{tabular}

Step 2: In the first place, the values presented in Table V. Were substituted in Eq. 1-3, to obtain the CTWF of the three classes of grey. As an example, the results of the first parameter (OD) are shown in Eq. 7-9.

$$
\begin{gathered}
f_{1}^{1}\left(x_{i j}\right)=\left\{\begin{array}{c}
1, x \in[0,1.3636] \\
\frac{0.9091-x}{0.9091-1.3636}, x \in[1.3636,0.9091] \\
0, x \in[0-9091,+\propto]
\end{array}\right. \\
f_{1}^{2}\left(x_{i j}\right)=\left\{\begin{array}{cc}
\frac{x-1.3636}{0.9091-1.3636}, & x \in[1.3636,0.9091] \\
\frac{0.7273-x}{0.7273-0.9091}, & x \in[0.9091,0.7273] \\
0, x \notin[1.3636,0.7273]
\end{array}\right. \\
f_{1}^{3}\left(x_{i j}\right)=\left\{\begin{array}{c}
\frac{x-0.9091}{0.7273-0.9091}, x \in[0.9091,0.7273] \\
1, x \in[0.7273,+\propto] \\
0, x \in[0,0.9091]
\end{array}\right.
\end{gathered}
$$

Then, from Table $\mathrm{V}$, the CTWF values were calculated using Eqs. 1-3. As an example, the results of monitoring point 1 and 2 , the results are shown in Table VI.

Step 3: From Table II, the weight of each grouping ( $n \_i j$ ) of each parameter was calculated by harmonic mean as detailed in Table VII.

Step 4: The values of the clustering coefficients $\sigma \_\mathrm{i}^{\wedge} \mathrm{k}$ were calculated using equation (5) and are shown ${ }^{-}$in Tables IX, X, XI, XII, XIII and XIV that will be presented in the results and discussions.

Step 5: The maximum values of the clustering coefficient were determined as shown in Table VIII. 
TABLE VI. CTWF VALUES OF THE FIRST TwO MONITORING

\begin{tabular}{|l|l|l|l|l|l|l|l|}
\hline Point 1 & $\mathbf{C 1}$ & $\mathbf{C 2}$ & $\mathbf{C 3}$ & $\mathbf{C 4}$ & $\mathbf{C 5}$ & $\mathbf{C 6}$ & $\mathbf{C 7}$ \\
\hline $\mathbf{f 1 j}(\mathbf{x})$ & 0.0000 & 0.0000 & 0.0000 & 1.0000 & 0.6092 & 1.0000 & 0.0000 \\
\hline $\mathbf{f 2 j ( x )}$ & 0.5366 & 0.0000 & 0.4219 & 0.0000 & 0.3908 & 0.0000 & 0.4847 \\
\hline $\mathbf{f 3 j} \mathbf{( x )}$ & 0.4634 & 1.0000 & 0.5781 & 0.0000 & 0.0000 & 0.0000 & 0.5153 \\
\hline Punto 1 & $\mathbf{C 8}$ & $\mathbf{C 9}$ & $\mathbf{C 1 0}$ & $\mathbf{C 1 1}$ & $\mathbf{C 1 2}$ & $\mathbf{C 1 3}$ & $\mathbf{C 1 4}$ \\
\hline $\mathbf{f 1 j ( x )}$ & 1.0000 & 0.0000 & 1.0000 & 1.0000 & 0.0000 & 1.0000 & 0.5326 \\
\hline $\mathbf{f 2 j ( x )}$ & 0.0000 & 0.0000 & 0.0000 & 0.0000 & 0.0000 & 0.0000 & 0.4674 \\
\hline $\mathbf{f 3 j ( x )}$ & 0.0000 & 1.0000 & 0.0000 & 0.0000 & 1.0000 & 0.0000 & 0.0000 \\
\hline Point 2 & $\mathbf{C 1}$ & $\mathbf{C 2}$ & $\mathbf{C 3}$ & $\mathbf{C 4}$ & $\mathbf{C 5}$ & $\mathbf{C 6}$ & $\mathbf{C 7}$ \\
\hline $\mathbf{f 1 j ( x )}$ & 0.0000 & 0.0000 & 1.0000 & 1.00 & 0.8851 & 1.0000 & 0.7932 \\
\hline $\mathbf{f 2 j ( x )}$ & 0.1440 & 0.0000 & 0.0000 & 0.0000 & 0.1149 & 0.0000 & 0.2068 \\
\hline $\mathbf{f 3 j ( x )}$ & 0.8560 & 1.0000 & 0.0000 & 0.0000 & 0.0000 & 0.0000 & 0.0000 \\
\hline Point 2 & $\mathbf{C 8}$ & $\mathbf{C 9}$ & $\mathbf{C 1 0}$ & $\mathbf{C 1 1}$ & $\mathbf{C 1 2}$ & $\mathbf{C 1 3}$ & $\mathbf{C 1 4}$ \\
\hline $\mathbf{f 1 j ( x )}$ & 1.0000 & 0.0000 & 1.0000 & 1.0000 & 0.0578 & 1.0000 & 0.9246 \\
\hline $\mathbf{f 2 j ( x )}$ & 0.0000 & 0.0000 & 0.0000 & 0.0000 & 0.9422 & 0.0000 & 0.0754 \\
\hline $\mathbf{f 3 j ( x )}$ & 0.0000 & 1.0000 & 0.0000 & 0.0000 & 0.0000 & 0.0000 & 0.0000 \\
\hline
\end{tabular}

TABLE VII. Clustering WeIGHT OF EACH PARAMETER

\begin{tabular}{|l|l|l|l|l|}
\hline Parameters & Criteria & Good & Moderate & Bad \\
\hline OD & C1 & 0.001 & 0.044 & 0.159 \\
\hline pH & C2 & 0.002 & 0.039 & 0.111 \\
\hline As & C3 & 0.004 & 0.046 & 0.068 \\
\hline Cd & C4 & 0.037 & 0.081 & 0.047 \\
\hline Cu & C5 & 0.212 & 0.046 & 0.054 \\
\hline Co & C6 & 0.014 & 0.152 & 0.044 \\
\hline Fe & C7 & 0.013 & 0.083 & 0.049 \\
\hline Mg & C8 & 0.004 & 0.041 & 0.073 \\
\hline Mn & C9 & 0.005 & 0.040 & 0.072 \\
\hline Hg & C10 & 0.034 & 0.148 & 0.043 \\
\hline Ni & C11 & 0.091 & 0.020 & 0.117 \\
\hline Pb & C12 & 0.049 & 0.036 & 0.063 \\
\hline Se & C13 & 0.009 & 0.050 & 0.058 \\
\hline Zn & C14 & 0.525 & 0.172 & 0.042 \\
\hline SUMA & & $\mathbf{1 . 0 0 0}$ & $\mathbf{1 . 0 0 0}$ & $\mathbf{1 . 0 0 0}$ \\
\hline
\end{tabular}

TABLE VIII. MAXIMUM CLUSTERING COEFFICIENT

\begin{tabular}{|l|l|l|l|}
\hline \multicolumn{2}{|l|}{ Yauli upstream } & \multicolumn{2}{l|}{ Andaychahua upstream } \\
\hline Stations & Good & PA-01 & Good \\
\hline Wet season & 0.598025423 & Wet season & 0.79018448 \\
\hline Dry Season & 0.879476417 & Dry Season & 0.86914266 \\
\hline Yauli downstream & & Andaychahua downstream \\
\hline Stations & Good & PA-02 & Good \\
\hline Wet season & 0.562789011 & Wet season & 0.81181683 \\
\hline Dry Season & 0.644790059 & Dry Season & 0.88265749 \\
\hline Yauli Quality & & Andaychahua Quality \\
\hline Stations & Good & Stations & Good \\
\hline PY-01 & 0.730181309 & PA-01 & 0.82133905 \\
\hline PY-02 & 0.5448226 & PA-02 & 0.83850656 \\
\hline
\end{tabular}

\section{RESUlTS AND DisCUSSION}

The analysis of affectation to bodies of water was made by the discharges of the mining company under study. Thus, the analysis was performed in two mining units which discharge into the Yauli and Andaychagua rivers in order to detect which deserves greater attention to water treatment, in order to reduce the impact on water bodies.

The upstream and downstream assessment was performed for each water body. The assessment was separated into wet and dry seasons in order to better assess the mining activity that discharges its waters into the river.

\section{A. About the Case Study}

Analysis of the Yauli River upstream and downstream from an industrial discharge point shows that there is no variation in the water quality rating; however, there is a slight decrease in the Clustering value of $25 \%$ which shows minimal but acceptable impairment. Table IX shows the Clustering values and the good score at the two sampling points since the values are higher in that score.

As shown in Table $\mathrm{X}$, in the dry season upstream the good water rating is $89 \%$ while in the wet season it is $59 \%$.

In the case of Table XI, it shows the results downstream at both times of the year. Decreasing the quality from $64 \%$ in dry season to $56 \%$ in wet season.

With the criteria in time flooded and low water is evident the affectation by climatic factors even more of the industrial presence of the zone. This variation is due to the increase of contact water generated by the rainy season concentration that although it would not be discharged directly this would be filtered by runoff into the river [23]. This is a consequence of the inadequate disposal of tailings and waste, as well as inappropriate methods for the disposal of industrial effluents that cause leaks and acid drainage [24].

Water quality assessment of the Yauli River at both times of the year shows minimal impact on river quality as the rating is good throughout the analysis. Even though there is a slight variation of $20 \%$ between upstream and downstream. On the other hand, it was evident that climatic factors in the low and high seasons influence water quality in the receiving body. Although it is possible that, from a geological point of view, the area has a natural influence on the presence of metals, both mining activity and the existence of mining environmental liabilities in the area are the two main factors that generate alteration of water quality [25].

TABLE IX. YAULI RIVER WATER QUALITY

\begin{tabular}{|l|l|l|l|}
\hline \multicolumn{1}{|c|}{ Seasons } & Good & Moderate & Bad \\
\hline PA-01 (upstream) & 0.8213 & 0.1774 & 0.2871 \\
\hline PA-02 (Downstream) & 0.8385 & 0.1575 & 0.3911 \\
\hline
\end{tabular}

TABLE X. PY-01 Station, UpSTREAM YAULi RiVER

\begin{tabular}{|l|l|l|l|}
\hline PY-01 & Good & Moderate & Bad \\
\hline Wet season & 0.5980 & 0.1822 & 0.3839 \\
\hline Dry season & 0.8795 & 0.0756 & 0.3197 \\
\hline
\end{tabular}


TABLE XI. PY-02 STATION, DOWNSTREAM OF THE YAULI RIVER

\begin{tabular}{|l|l|l|l|}
\hline PY-02 & Good & Moderate & Bad \\
\hline Wet season & 0.5628 & 0.2346 & 0.4792 \\
\hline Dry season & 0.6448 & 0.1996 & 0.3927 \\
\hline
\end{tabular}

The analysis of the Andaychagua River, by another discharge point of the same mining company under study, shows that the quality of its water is of good value as shown in Table XII, since the highest values of clustering are in this category in the two sampling stations. Table XII with the clustering values is shown below.

The analysis of water quality in the Andaychagua River shows a slight improvement in its waters after the industrial discharge. This would indicate that the effluent does not significantly impact the physical-chemical quality of the receiving body; it would also be due to the contributions of tributaries from the Pacchapuquiopampa stream that dilutes the discharge made upstream in a greater proportion.

Over the years, evaluations of this river have shown that it does not exceed the limit values, as indicated in a study conducted by the DGCA-MINAM and DIGEDA in 2009. Similarly, a study of the Mantaro River shows that the receiving bodies of this mine's effluents indicate both upstream and downstream compliance with Environmental Quality Standards [26].

Analysis of the river based on the time of year criteria shows the influence of climatic factors on water quality in the receiving body. Like the Yauli River, water quality in the dry season was better along the entire stretch of the river studied.

Table XIII is shown. With the data of the upstream season, presenting in dry season a value of $87 \%$ of good quality, while in wet season a value of $79 \%$.

Table XIV shows the clustering results in the two seasons downstream of the river. The dry season shows an improvement in its waters with a value of $88 \%$ in the good classification.

TABLE XII. ANDAYCHAGUA RIVER

\begin{tabular}{|l|l|l|l|}
\hline SEASONS & Good & Moderate & Bad \\
\hline PY-01 & 0.7302 & 0.1873 & 0.3604 \\
\hline PY-02 & 0.5448 & 0.2935 & 0.4178 \\
\hline
\end{tabular}

TABLE XIII. STATION PA-01, UPSTREAM ANDAYCHAGUA RIVER

\begin{tabular}{|l|l|l|l|}
\hline PA-01 & Good & Moderate & Bad \\
\hline Wet season & 0.7902 & 0.1750 & 0.3339 \\
\hline Dry season & 0.8691 & 0.1632 & 0.2150 \\
\hline
\end{tabular}

TABLE XIV. PA-02 StATION, DOWNSTREAm OF ANDAYCHAGUA River

\begin{tabular}{|l|l|l|l|}
\hline PA-02 & Good & Moderate & Bad \\
\hline Wet season & 0.8118 & 0.1338 & 0.3998 \\
\hline Dry season & 0.8827 & 0.1838 & 0.3156 \\
\hline
\end{tabular}

The analysis of the Andaychagua River shows an improvement in the quality of its water in both the dry and wet seasons, the rating is good throughout the river, even more so after the discharge slightly improves the quality by $8 \%$. This would indicate that the river is not affected by industrial effluent; however, a better analysis with a greater weighting of critical parameters would be necessary. As was done in a study of the Santa River basin, 21 monitoring points were analyzed, with $47.6 \%$ of the points being of good quality and $19.1 \%$ of low quality [12].

The evaluation of water quality in the Yauli and Andaychagua Rivers by the dumping of industrial effluents from the same mining company, using the Grey Clustering methodology, gives the rating of good before and after dumping. However, this analysis was carried out with harmonic weighting, which is recommended to be done by experts or by evaluating the criteria of weighting of the parameters according to the impact on each receiving body or by the influence of these on water treatment.

A statistical analysis of all 2019 values was carried out in Yauli and Andaychagua rivers to counteract the results with the Grey Clustering method and compare them with the ECA Water Category 3, vegetables irrigation and animals drink.

The results of the statistical analysis of the Andaychagua river showed that at least 6 chemical parameters $(\mathrm{pH}$, sulphates, $\mathrm{Fe}, \mathrm{Mn}, \mathrm{Pb}, \mathrm{Zn}$ ) exceeded the ACE for vegetable irrigation and animal drinking, showing its impact on the receiving body. In view of this, for a water evaluation with fuzzy logic, statistical analysis should be taken into account first in order to assess with greater weight these critical parameters and thus evaluate the total quantitative quality of the river.

\section{B. About the Methodology}

In the grey grouping method the grouping coefficients are important factors for the final evaluation, which are obtained with the bleaching functions and the weightings, the latter help to obtain reliable results in the evaluation. Being important to highlight the weights, they incur an important effect in the calculations since the greater weight to each criterion this can make us vary the analysis giving us other results that is why it is important to detail the weighting used for the parameters. Likewise, there can be different methods to determine the weighting, not only with the harmonic method. There are also methods such as the Delphy method (based on expert consultation) [27], mixed weighting method [28], weighting of the INSF method [29], etc. These can complement the study to find the appropriate weights for each parameter being analyzed.

There are other methodologies that are also used for the evaluation of water quality such as the INSF methodology, which considers the characteristics that the water body must present for its use as human consumption, this already has established weights for specific parameters, as well as the Water Quality Index in surface currents (ICA), The Prati Index is one of the most commonly used in water quality assessment studies. It characterizes water in five classes, each with a range of established values [30]. This shows us that the 
Grey Clustering methodology has a better range of application for water quality since it can be adjusted to the number of parameters with which you want to evaluate and also adds a weighting to each to determine the weighting of the criteria, this weighting can be supplemented with other methodologies already mentioned to improve their effectiveness in the evaluation by adjusting to the place where the study is conducted in terms of conditions and characteristics, compared to existing methodologies which already have weights and parameters which make them a limitation when evaluating water quality.

Based on the review in Section II, the analysis of the Andaychagua River shows an improvement in water quality in both the dry and wet seasons, the rating is good throughout the river, more so after the discharge slightly improves the quality by $8 \%$. This would indicate that the river is not affected by industrial effluent; however, a better analysis with a greater weighting of critical parameters would be necessary. As was done in a study of the Santa River basin, 21 monitoring points were analyzed, with $47.6 \%$ of the points being of good quality and $19.1 \%$ of low quality [12].

\section{CONCLUSIONS}

The Yauli River shows good water quality according to the clustering methodology along the river, even in wet and dry seasons. Although this variation infers a low proportion of water quality being lower in wet periods, this is due to the influence of rainfall on contact water, even so the quality is good. For the Andaychagua River, a good quality rating is shown both upstream and downstream from the industrial discharge. In both rivers there is an alteration of their waters due to climatic factors that slightly modify their water quality. The results with the clustering analysis show that the river is not drastically affected by the industrial mining effluent, however, there is a bias in the analysis since the weighted values were made in a harmonic way to which one could have chosen to recommend to experts, and qualify some parameters that are of greater impact to the receiving body.

The Grey clustering methodology helps to assess water quality in an objective way, based on weights on the parameters that are evaluated, this can be complemented with more restrictive methods for the weights can be found those that are appropriate to the conditions and characteristics of the place of study.

The proposed research is a starting point for the evaluation of water quality, in natural bodies, applying diffuse logic. There are several applications of Grey Clustering; however, water quality assessment is not very widespread. Therefore, taking this research as a reference, the evaluation can be carried out by taking a greater number of monitoring points that show results in greater detail, verifying the impact that mining activity causes not only on rivers, but also on lagoons, and even sediment evaluation could be applied.

\section{REFERENCES}

[1] H. Huisa and I. Rodríguez, "Modelamiento en la evaluación del potencial de recursos minero metálico en la región Junín," XVIII Congr. Peru. Geol., pp. 1-4, 2016.

[2] C. Meza, P. Luis, and C. Sánchez, "Universidad Nacional Mayor de San Marcos Facultad de Ciencias Biológicas Escuela Académica Profesional de Microbiología y Parasitología Evaluación de hongos resistentes a Cr ( VI ) y Zn ( II ) y su capacidad de bioadsorción en solución acuosa , aislados d," 2012.

[3] J. Cayetano, "Cumplimiento de la normatividad ambiental por el sector minero metalúrgico y su impacto ambiental en el río Mantaro - Región Junín," 2013.

[4] DIGESA, "Monitoreo del rio SanJuan - Mantaro y Principales Afluentes,” 2008. [Online]. Available: http://www.digesa.minsa.gob.pe/ DEPA/rios/2008/SAN_JUAN_MANTARO_2008_ii.pdf.

[5] W. Y. Chang, "Application of grey clustering approach and genetic algorithm to partial discharge pattern recognition," WSEAS Trans. Syst., vol. 8, no. 12, pp. 1273-1283, 2009.

[6] S. Liu, J. Forrest, and Y. Lin, Grey Systems: Theory and Applications, Springe. Berlin, 2010.

[7] L. Ke, S. Xiaoliu, T. Zhongfu, and G. Wenyan, "Grey Clustering Analysis Method for Overseas Energy Project Investment Risk Decision," Syst. Eng. Procedia, vol. 3, no. 2011, pp. 55-62, 2012, doi: 10.1016/j.sepro.2011.11.008.

[8] W. Liu et al., "Key indices of the remanufacturing industry in China using a combined method of grey incidence analysis and grey clustering," J. Clean. Prod., vol. 168, pp. 1348-1357, 2017, doi: 10.1016/j.jclepro.2017.09.078.

[9] C. Li, K. Chen, and X. Xiang, "An integrated framework for effective safety management evaluation: Application of an improved grey clustering measurement," Expert Syst. Appl., vol. 42, no. 13, pp. 55415553, 2015, doi: 10.1016/j.eswa.2015.02.053.

[10] Q. Tan, T. Wei, W. Peng, Z. Yu, and C. Wu, "Comprehensive evaluation model of wind farm site selection based on ideal matter element and grey clustering," J. Clean. Prod., vol. 272, p. 122658, 2020, doi: $10.1016 /$ j.jclepro.2020.122658.

[11] C. Zhu and N. Li, "Study on Grey Clustering Model of Indoor Air Quality Indicators," Procedia Eng., vol. 205, pp. 2815-2822, 2017, doi: 10.1016/j.proeng.2017.09.895.

[12] A. Delgado and D. Edgar, "Artificial intelligence model based on grey systems to assess water quality from Santa river watershed.," Electron. Congr. (E-CON UNI), pp. 1-4, 2017, doi: 10.1109/ECON.2017.8247310.

[13] A. Delgado, A. Aguirre, E. Palomino, and G. Salazar, "Applying triangular whitenization weight functions to assess water quality of main affluents of Rimac river," Proc. 2017 Electron. Congr. E-CON UNI 2017, vol. 2018-Janua, pp. 1-4, 2017, doi: 10.1109/ECON.2017.8247308.

[14] A. Delgado, J. Soto, and F. Valverde, "Evaluation of the drinking water consumption in Lima city using the grey clustering method," Proc. LACCEI Int. Multi-conference Eng. Educ. Technol., vol. 2019-July, no. July, pp. 24-26, 2019, doi: 10.18687/LACCEI2019.1.1.421.

[15] L. F. Zhou, S. G. Xu, and W. G. Sun, "Comprehensive evaluation on water environment quality of Zhalong wetland based on grey clustering method," J. Dalian Univ. Technol., vol. 47, no. 2, pp. 240-245, 2007.

[16] L. Wang, K. Lai, and W. Zhou, "Application of grey clustering method for water quality evaluation in Fenchuan river Yan'an Baota area," ISWREP 2011 - Proc. 2011 Int. Symp. Water Resour. Environ. Prot., vol. 2, pp. 838-841, 2011, doi: 10.1109/ISWREP.2011.5893142.

[17] Ministerio del Ambiente, "Estándares de Calidad Ambiental para Agua (ECA)," El Peru., pp. 6-9, 2017, [Online]. Available: http://www. minam.gob.pe/wp-content/uploads/2017/06/DS-004-2017-MINAM.pdf.

[18] Chile Sustentable, "Marco Jurídico para Gestión del Agua en Chile: Diagnóstico y Desafíos," pp. 1-16, 2010.

[19] Ministerio de Agricultura, "Reglamento de la Ley General de Aguas. Decreto Supremo N 261-69AP," no. 17752, pp. 31-67, 1969.

[20] R. B. de Venezuela, "Normas para la clasificacion y el control de la calidad de los cuerpos de agua y vertidos o efluentes liquidos." Venezuela, p. 24, 1995.

[21] P. Steduto, T. C. Hsiao, E. Fereres, and D. Raes, Respuesta del rendimiento de los cultivos al agua, vol. 66. 2012.

[22] SEAM, Resolucion 222/2002. Paraguay, 2002, p. 6.

[23] F. M. Romero, M. A. Armienta, M. E. Gutiérrez, and G. Villaseñor, "Factores geológicos y climáticos que determinan la peligrosidad y el 
impacto ambiental de jales mineros," Rev. Int. Contam. Ambient., vol. 24, no. 2, pp. 43-54, 2008.

[24] M. Núñez Aylas, E. Benites Alfaro, and M. Zevallos León, "Evaluación de la calidad del agua asociado al drenaje ácido de mina (DAM), en el río Yauli en época de estiaje distrito de Yauli - Junín, 2013,” Ucv - Sci., vol. 6, no. 1, pp. 25-30, 2014.

[25] H. Calla, "Calidad del agua en la cuenca del río Rímac-Sector de San Mateo afectado por las actividades mineras," 2010.

[26] J. Cayetano, "Cumplimiento de la normatividad ambiental por el sector minero metalúrgico y su impacto ambiental en el río Mantaro - Región Junín," Universidad Nacional Del Centro Del Centro De Posgrado, 2013 .
[27] R. Samboni, Y. Carvajal, and J. Carlos, "Revisión de parámetros fisicoquímicos como indicadores de calidad y contaminación del agua," Rev. Ing. e Investig., vol. 27, no. 3, pp. 172-181, 2007.

[28] J. Zonensein, M. G. Miguez, L. P. . De Magalhães, and M. G. Valentin, "Flood risk index as an urban management tool. International Conference on Urban Drainage," Int. Conf. Urban Drain., no. Edinburgh, Scotland, UK., 2008.

[29] M. Castro, J. Almaida, J. Ferrer, and D. Díaz., "Indicadores de la calidad del agua: evolución y tendencias a nivel global. Ingeniería Solidaria," Ing. Solidar., vol. 10, no. 17, pp. 111-124, 2014, doi: http://dx.doi.org/10.16925/in.v9i17.811.

[30] L. Pratti and R. Pavanello, “Assesment of Surface Water Quality By A single Indx Of Contamination,” Water Resour. Res., vol. 5, pp. 456-467, 1971 . 